\title{
Pennsylvania State Forest School Forest.
}

By

E.A. Ziegler - Director Pennsylvania State Forest $\mathrm{S}_{\mathrm{C}}$ hool.

Presented on the occasion of the annual dinner

of the Foresters Club and Alumni,

University of Toronto.

State Forest Policy.

Pennsylvania once contained one of the

richest iorests of eastern Americe. Her 29 million acres of land were covered with magnificent stands of white pine, hemlock, maple, beech, birch, and iurther south chestnut and the various oaks. Only 29 years ago (1899) Pensylvania reached her maximua lumber output of two billion three hundred and thirty three million board feot. The la rger part of the state had already been swept of its forest however, and fire was completing the ruin of her forest land. To-dey only a few pitiful remmants of the great forest remain, and the lumber cut has dropped to 300 million feet about thirteen percent of the peak and thirteen percent of what its thirteen million acres of forest land can continuously produce when reforested. The state to-day imports seven-eighths of its needs in forest products and pays out 100 million dollars that its own mountainlands should keep within its borders.

Pennsylvania's forest policy may be said to have developed sinultaneously with, but more or less independently of, the forest policy of the nation. The early national policy may be said to hove centered about a few men, anong which Dr. B.E.Fernow's name stands out most prominently. This policy became agressive after the Natibnal Forest Reserve Act of 1891 enabled President Harrison to begin the organization of the great string of National Forests that now form the backbone of the government forestry development south of the Canada line. In the same way the early forest policy of the State of Pennsylvania is devoloped about Dr. Joseph T. Rothrock. As State Cominissioner of Forestry, he secured the adoption of a forest land buying policy by the State Legislature in 1897 and the purchase of the first cut-over lands followed the next year - 1898 .

Land Purchase.

From 1898 to 1902 the state under Rothrock acquired about a half million acres and to the present has acquired $1,132,444$ acres, costing $\$ 2,561,572$ or $\$ 2.26$ per scre. Added expenditures since purchnse have increased this cost to $\$ 7.00$ per acre 
with all improvements. The acquisition policy stagnated after 1921 and is just now being revitalized. An appropriation of $\$ 500,000$ for this biennium has been made which will add in the neighbourhood of 125,000 acres to the state holdings. The Gane Commission will expend from its annual hunting license receipts of about $\$ 900,000$ about $\$ 300,000$ for the biennium for the purchase of forest land for state game rofuges and open hunting lands, adding another 75,000 acres to the state domain. Fritten offers for the sale of 720,000 acres are in hand and 50,000 have beon purchesed already this year for less than $\$ 4.00$ averege per acre. There is a state bond issue of twenty-five milition dollars to be voted on this fall to corplete the purchase of the denuded forest lands. Much credit belongs to the Secretary of the Department of Forests and Waters, Mr. Charles E. Dorworth, and to the State Forester, Dr. J.S. Illick, for the speeding up of this policy.

It may be noted that the state purchases land under a price limit. The first million acres vero acquired at an average price of $\$ 2.26$ per acre with a price limit of $\$ 5.00$. This limit has now been raised to $\$ 10.00$ per acre but the policy is to have the State buy only the lands that private capital will not hendle. A price limit is deemed valuable to prevent inflation of values. The first purchases this yoar were made at around $\$ 2.00$ por acre and widely advertised. If the bond issue passes, the completion of the purchase programe is in sight. About five million acres of the thirteen milizon should be in the care of the state.

The land already acquired has been protocted and developed. Forty-soven hundred miles of road and trails have been built; one hundrod and twelve fire towers cover the sta.te and private forest lands within its boundaries; the state is districted. into 24 districts in cinge of graduate foresters from the State School; fifty-six rangers are employed on the state forests; thirtyone hundred and seventy-two local and five hundred and sixteon special fire wardens complete the fire extinction force. These men are paid only for actual time on fires, or spocial duty.

The two year apropriation embraces

$\begin{array}{lr}\text { Administration, } & \$ 1,591,000 \\ \text { Tax appropriation, } & 115,970 \\ \text { Fire extinction, } & 200,000 \\ \text { Land purchese, } & 500,000 \\ \text { Fire deficiency, } & 100,000 \text { (almost all unused) } \\ \text { Cook Forest Perk, } & 450,000\end{array}$

The purchase cost of the $1,132,44$ acres was $\$ 2,561,572$. Total tax apropriation to dete $\$ 838,000$, and purchase 
price plus expenses of development in the 25 years, total about nine million dollars. The cash sale volue of these lands would be far above this to-day (conservatively placed at 14 million dollars at wrocking value). Receipts have totalled about $\$ 735,000$ to date. The gross income is now growing rapidly being $\$ 96,000$ in 1927. Over $\$ 427,000$ of the receipts have gone into the State School Fund.

Recreational. Value.

Timber income develops rather slowly as 60 to 100 years are necessary to develop heavy stands of good sav timber. The recreational use of these lands is groving by leaps and bounds and furnishes early returns. The state is leasing already over 1800 permanent camp sites (average rentel about $\$ 9.00$ per year) bringing in an annual revenue of about $\$ 16,000$. The income from forest camps alone will ultimately pay the interest on a sizeable part of the purchase price of the lands. On one state forest camp site rentals alreedy pay interest on the cost of the forest, and the valus of the camp buildings exceeds the cost of the entire forest. The buildings are taxable by the local government.

Gams is more abundant than in any state in the Union and the forests support the largo independent Gano and Fish Comissicn programs financed by bunting and fishing licenses bringing in cinnualy over a million dollars.

At least seven large water and power projects have either been completed or are definitely bogun on the Susquehanna, upper Delewre and Ohio River watersheds, for which the headwater state forests will heve a large significance.

The large state nurseries should not be neglected. They furnish 16 million trees each year for reforestation purposes. Tax Policy。

To prevent undue hardship on the local government units through loss of texes on stete lands, the legis lature appropriates annuclly $5 \%$ por acre to the local units.

If local texation hecomes too heavy the private forest owmer may have his forest land declared "Auxiliary State Forest" when ho is assessed at not over $\$ 1.00$ per acre and pays a 10 percent final yield tax. A small area only has found it desirablo to enter this class. 
The State Forest School.

This thorough-going state forest policy had hardly begun to gain impetus in 1902 when tho noed for trained foresters to protect, organize, reforest and develop those lands became acute. The fow early schools did not have available graduates. It seemed of doubtful wisdon to import Europoan foresters with a totally different economic background. The refusal of one or two colleges that might have qualified for developing a course in forestry, causod a critical survey of the educational situation. It appoared that often no great consideration vas given to the oquipment or location of a forest school with respect to a practice forest and forest nursery. It might be observod that the newer pedagogy for professionel schools was demending closer and closor co-ordination between theoreticel instruction and its prectical application. Thus overy medical college in the land must hevo its hospital at hand and medical practice is only permitted after an additional hospital interneship after graduation. Teachers collogos wore roquiring the addition of practice "model" schools. Engineering s chools wero requiring and giving credit for shop work - often in comorcial plants. Agricultural colleges must have their experimental and domonstration farms. Could the forest school ignore this movement in the new professional school pedagogy? Could occasional trips and inspections and forest camps take the place of a school forest and nursery in situ or should they be regarded only as collaterol aids to tho school forost? West Point and Annapolis as govornmont servico schools suggested the establishment of a state forest-sorvico school. The prosont law establishing this school contains this significant statoment of duty of the present Depertment of Forests and Waters,"to continue at the school professional oducation in forostry and mantain a close association of thoory and prectice".(Italics mine).

Accordingly in 1903 the State Forost School was opened by $\mathrm{Dr}$. Rothrock under tho direction of Mr. Goorgo H. Wirt, under tho first mo "State Forost icedomy" on the Mont Alto Stato Forest in the Blue Ridgo or South Mountains. With the Biltmore School discontinued and the first Cornell School also discontinued, this is the socond oldest forost school in imorica. Tho school is thus diroctly undor tho Stato Forest idministration and is a stete school in the fullest sonso of the torm. From tho boginning it has supplied the forestors for tho Stato Forest Sorvico. Lis tho list of applicants for ontranco grow, tho $S$ chosl raisod its lirit of attondance from 30 to 80 students, but ovon now only ono-half tho applicants filing crodontials from within tho stato aro accoptod, and, for the prosont, applicants from outsido tho state cro rofusod. This should be only tomporary. 
The School Forest.

This idea of a State Service school with omphasis on the closer co-ordination of tho thoorotical instruction with the prectical, lod Doctor Rothrock and Mr. Goorgo H. Wirt, the first Director, to locato it on the Mont Alto State Forest. Tho nucleus of the state forest holdings (ombracing tho contiguous Michaux and Wont Alto Stato Forests), totalling almost 70,000 acros in tho South Wtns. botween tho Susquehanna and Potomec watersheds, wore the lands of threo old charcoel iron furnacos. The land was cut over from ono to throo timos and burnod ovor froquently. Parts wero roduced to scrub oak barrens, but othor largo aroas had a most promising cover of chestnut and oak coppico. Thito pino, homlock, birch and (soft meple), and tulip poplar occupied tho coves. Chostnut, white, rod, scarlot and black oaks occupiod the slopes vith rock or chestnut oak and chestnutend some pitch pine on the ridges.

Firo Protection.

Tho School immediatoly, on ostrblishmont, orgenizod for fire protection. Wooden fire towors (sinco roplacod with stool) voro oroctod; tolophono linos installod; roads oponod and robuilt. In placos tho scrub oak (Quorcus ilicifolia or punila) was so donso aftor the firos that the ongineoring class had to hack their way through when leying out road grades. The nativos wore not in sympathy with tho work. Incondiarism was rapant. But firo organization, loctures, omploymont, troo planting ond resulting public intorost slowly dovolopod sympathy with tho porostry viowpoint. Tho students horo aro ablo to loarn to know tho forost population and to doal with it fairly and intelligontly - one of tho most valuablo parts of a forostor's training. Thoro aro at hand accurato figuros for the progross of tho protection vork from 1910 to 1925. Tho i igures apply to the protoction of the 23,000 acros of $s$ chool forost and 17,000 acres of private forest adjoining.

Fire Data. by 7-Yonr Poriods.

\begin{tabular}{|c|c|c|c|}
\hline & $1910-1917$ & 1918-1925 & $\begin{array}{l}\text { Docroaso } \\
\text { porcont. }\end{array}$ \\
\hline Av. Piros por yoar & 28 & 18 & 37 \\
\hline Av. area burnod & 1150 & 239 & 79 \\
\hline Av. sizo por firo (acros) & 40.6 & 13.3 & 67 \\
\hline Money loss (dollars) & 2500 & 575 & 79 \\
\hline Part of fires incondiery (porcont) & 21.4 & $8 \cdot 6$ & 60 \\
\hline
\end{tabular}

Firo protoction costs 1911 - '21 woro 5.2 conts -- 
including ovorhead and one half tho road maintonance cost. Thoy aro now falling on the firo extinction sido.

Wach of the four classes at tho Forost School has a fully organized and equippod firo crow of 15 to 25 men. They are an important factor in forest firo extinction within a radius of 30 milos of the School. Fire crews occasionally assist Maryland in large fires. This training is of utmost valuo to tho futuro forostor.

Forest Stock.

i $10 \%$ strip survoy showod troes four inchos and over in diameter on the 23,000 acres of school forest --

Chestnut 10 million cu. ft.
Oaks ond others 15 "
Of this $70.5 \%$ was $4 "$ to $10 "$ in diamoter
$22.5 \%$ "11" to $17 "$ "
$7.0 \%$ "18" and over "

This showed (including the chostnut) around 1100 cu. ft. per acre 4" and up. The evorage age of the forest was about 35 years or the increment was about $32 \mathrm{cu}$. ft. por annum. This was conly about $80 \%$ of expectancy with fires oliminatod, as tho avorago stand at 50 yoars should be about $2,000 \mathrm{cu}$. $\mathrm{ft}$. (thinnings not includod).

Utilization.

The loss of the chostnut ( $40 \%$ of tho stock) by the chestnut blight startod the first largo scolo utilization work. From 1920 to ' 27 there woro markotod about 35,000 cords oi doed chostnut, mostly as tanning extract wood, stavo rood and fuol nood. Somo of the largor material mado polos and tios and a littlo lumber. In thoso scvon yoars $\$ 200,000$ worth(gross - wood s.t mill and railway siding) of dead undersizod chostnut wes salvaged from tho 23,000 acro forest costing originally $\$ 80,000$. To dato tho 23,000 acro school forest has had a gross income (excluding nursory stock) of ovor $\$ 260,000$ which is $36 \%$ of tho total incora from the $1,132,000$ acros of steto forosts: viz $\$ 735,000$. This is only a samplo of what ro-ostablishod forosts can bo mado to do in wago production.

Tho docroaso in firos has somowhat offsot tho loss in incroment through the loss of the chostnut. Tho incromont is again approaching $30 \mathrm{cu}$. ft. with tho prospoct of further incroaso to probably $60 \mathrm{cu}$. ft. ultimatoly, (thimnings includod). in approximato moan rato of growth shows 1 inch in dinmotor in 6 yoars.

Chostnut polos nottod $\$ 9.00$ por cord stumpago, whilo the mass of the snall sized matorinl nottod about $50 \%$ por cord only. 
This shows a rathor unusual price incroment with size - a factor always to be calculated on, however, in forestry. Mixed hardwood fuel sawed stove length sells for $\$ 5.50$ per cord on the forest road. Mill run lumber brings $\$ 35.00$ per $\mathbb{M} \mathrm{ft}$. at the railroad on the forest.

Tho working plan soon to be published will call for e. 100-year rotation for timber, with a 30-year roturn for thinning and cleaning.

Local fuel markets can not absorb all the thinnings. A re-adjustmont of freight retes will be necessary when the coal mines oast and west should become a satisfactory market for all small sized metorial. This will in time require marketing 4,000 to 5,000 cords of thinnings annualiy. The prosent thinning cut is set at 3,000 cords. In the next 35 years tho annual sew timber cut should rise to 3 million foet and finally to 6 million feet.

\section{Other Forest Uses.}

The school forest contains numorous leased camp sitos; two borough wator supplias; ono stato sanatorium; one park; a most plentiful game supply and some trout stroams.

Hardwood Conversion.

Where the chestnut approachod a $60 \%$ stand, underplanting the hardiood romnant with conifers is being tried. The old fields have all been reforested with conifers. Hundreds of acres of white pine, with some norvay spruce, scotch pine and pitch pine are succeoding. Some of the earlior plantings are being thinned for the first time. It is hopod to increase the percentage of conifers on the forest materialiy.

Nursery•

A 10 acre nursory with ovorhead wator system has an annual output of 4 million treos.

This school forest has an ideal location for exeruplifying al 1 forest uses - timbor, veter, health, and recreation. 